\title{
VEINTE AÑOS DE CULTURA
}

\author{
Carmen Lucia Moccia*
}

Università degli Studi di Salerno

Cuando nos hallamos frente a realidades como la de Cultura Latinoamericana. Revista de Estudios Interculturales, enseguida nos damos cuenta de que raramente estas son el producto de rutas estrictamente planeadas, o de pronósticos acertados, sino más bien de sutilezas de particulares que se arriesgan, apuestan e invierten en el valor de un proyecto. Esto ocurre a Cultura Latinoamericana, que este año celebra su vigésimo aniversario: la revista nace en 1999, fue fundada por Aldo Albonico (lamentablemente fallecido durante la publicación del primer volumen) y Antonio Scocozza quien la dirige junto con Giuseppe Cacciatore. El origen de Cultura Latinoamericana está ligada al nacimiento del I.S.La. (Istituto di Studi Latinoamericani) cuyo origen se vincula a su vez a un precioso donativo de libros por parte de Rafael Di Prisco, catedrático venezolano, a final de los años noventa del siglo pasado. Alrededor de 30.000 volúmenes llegaban en las manos de Antonio Scocozza, a quien estaba dedicada esa donación; no quiso desperdiciarla en una biblioteca particular, por lo que junto con la administración provincial de Salerno y con la colaboración del ayun-

\footnotetext{
* Magister en Ciencias Pedagogicas por la Universidad de Salerno. Sus intereses se dirigen a las figuras femeninas en la pintura latinoamericana del siglo XX. ORCID: https://orcid.org/00000001-7947-074X. Contacto: cl.moccia@gmail.com
}

Referencia: Moccia, C. L. (2019). Veinte años de Cultura. Cultura Latinoamericana, 30(2), pp. 333-336. DOI: http://dx.doi.org/10.14718/CulturaLatinoam.2019.30.2.15 
tamiento de Pagani, fundó y dirigió el I.S. La que, desde el principio, se hizo cargo de publicar Cultura Latinoamericana.

Actualmente Cultura Latinoamericana es la revista de la Maestría en Ciencia Política, con énfasis en Paz e Integración, de la Universidad Católica de Colombia en convenio con la Università degli Studi di Salerno. Con algunas modificaciones ocurridas en el trascurso de los años, hoy en día la revista está formada por cinco secciones: "Historia y política", "Historia de las ideas y de la cultura", "Economía y derecho", y "Estudios ibéricos"; la sección "Notas y discusiones" está dedicada a reseñas y ensayos bibliográficos que contribuyen al desarrollo de una reflexión crítica y al intercambio de diferentes puntos de vista sobre múltiples temáticas y resultados de investigación. Desde 2011 ya no es más una publicación anual, sino semestral.

Los treinta volúmenes que salieron a lo largo de los últimos veinte años varían también por su diseño gráfico, coherentemente con los diferentes editores que publicaron la revista: Edizioni del Paguro, Oèdipus, Instituto Caro y Cuervo, Planeta.

Lejos de querer aburrir al lector con cuentos demasiado prolongados y difíciles de resumir fugazmente en veinte años de análisis, investigaciones, logros, emociones y esperanzas, me gustaría llamar la atención sobre el trabajo hecho sobre el índice onomástico y el índice volumen por volumen, que representan la verdadera esencia del proyecto Cultura.

Tomando prestadas las palabras de Salvador Novo, sería posible interpretar la historia editorial de Cultura latinoamericana como el viaje de un humanista que descubre el paisaje en función del hombre, esto es, un viaje de exploración donde se han empleado y se siguen empleando enfoques epistemológicos diferentes para el análisis y el estudio de la muy compleja realidad latinoamericana y caribeña, además de ibérica. La revista plantea, desde distintos ámbitos culturales, cuestiones y asuntos diferentes: por ejemplo, estudiosos de literatura investigan sobre temáticas relacionadas con las producciones literarias del mundo latinoamericano, de ahí que las obras de Gerbasi, Gallegos, Borges, García Márquez y muchos otros autores se encuentren contextualizadas, analizadas y actualizadas a través de varias y originales llaves de lectura entre presente y pasado.

Numerosos historiadores han examinado varios aspectos, teniendo en cuenta sobre todo los últimos dos siglos de la historia latinoamericana, desde las negociaciones de paz entre la Gran Colombia y España hasta los conflictos políticos y procesos de democratización en 
Latinoamérica, pasando por "los gritos de Córdoba" y el movimiento zapatista en México.

Los aspectos económicos y sociales del subcontinente están analizados desde diferentes enfoques: derecho, economía, ciencias políticas, sociología, antropología. De esta forma los investigadores han profundizado, por ejemplo, en el Constitucionalismo y los derechos de los pueblos indígenas en Venezuela, la construcción de la identidad y autenticidad en Latinoamérica, la política y la cultura como llaves para el análisis antropológico de la identidad, los efectos de la crisis de los años 2000 en el debate económico y contemporáneo, así como en el tema de la renovación de las ciencias sociales en América Latina a través de las obras de autores como Gino Germani. Sin embargo, la variación es connatural al uso lingüístico y una lengua como el español, tan extensa geográfica y diacrónicamente, muestra usos distintos y preferencias comunicativas variadas: esas variaciones quedan investigadas por los colaboradores de la revista desde el punto de vista semántico, gramatical, didáctico, paremiológico, etc. Por ejemplo, algunos estudios se interesan por el empleo de materiales multimediales auténticos en la enseñanza universitaria del español como lengua extranjera, por la presencia de la paremiología europea en la cultura latinoamericana, por los marcadores y conectores del discurso en el aula para el desarrollo de la expresión lingüística, por la relación entre política y discurso en América Latina.

Otras aportaciones se detienen sobre el pensamiento de importantes pensadores latinoamericanos y sobre cómo las ideas y los pensamientos de distintos intelectuales procedentes de diferentes áreas culturales pueden ser "empleados" para explicar la realidad latinoamericana. Sin embargo, merecen una atención especial las filosofías que marcaron el concepto de América Latina unida, la idea de lucha y renovación de un pueblo en demanda de ese surgimiento, así que se señala a Leopoldo Zea y el nacimiento de la conciencia americana: el reconocimiento de una cultura entre compromiso, responsabilidad y circunstancia, el humanismo práctico y latinoamericanista de José Martí, mitos de la comunidad y políticas de la identidad entre filosofía y acción política en Europa y en América Latina. Cabe subrayar que los autores que, en el trascurso de estos veinte años, han participado en el crecimiento del proyecto Cultura, tienen orígenes académicos distintos, no solamente por lo que se refiere a las disciplinas, sino también desde el punto de vista geográfico: la mayoría de los autores, por supuesto, son latinoamericanos pero, junto a ellos, hay muchos autores europeos, 
sobre todo italianos, lo cual pone en evidencia el vínculo solidario entre América Latina e Italia.

Sin embargo, como todas las culturas, la cultura latinoamericana ha de considerarse como un organismo vivo que se alimenta continuativamente de nuevos valores universales procedentes, no solo de la llamada cultura occidental, sino también de muchas otras culturas a través de un intercambio mutuo en el no solamente se beneficia de distintos aportes, sino que ella misma excede los límites de sus fronteras geográficas y es reconocida como parte integrante en la configuración de un "saber universal". De esta manera, Cultura latinoamericana. Revista de Estudios Interculturales se hizo, y todavía sigue, haciéndose cargo de impulsar y promover una praxis investigadora en la que cabe la reivindicación de un "yo" histórico-cultural que logra ser reconocido no solo en la diferenciación crítica de la globalidad, sino también en su ontológica multiplicidad. Es una América Latina cuyo pasado colonial y lengua común nos permiten pensar en una cultura como espacio común y, al mismo tiempo, como puesta en común de un espacio vivido por específicas particularidades con respecto a las cuales Cultura Latinoamericana se convierte en "Culturas Latinoamericanas". 